\title{
Hubungan Anemia pada Ibu Hamil dengan Kejadian Persalinan Prematur di RSUD Dr. Moewardi Surakarta
}

\author{
Saskia Nandatari ${ }^{1}$, Yudhistya N Insan ${ }^{2}$, Widardo ${ }^{3}$ \\ 1.Program Studi Kedokteran Fakultas Kedokteran Universitas Sebelas Maret \\ 2.Bagian Obstetri dan Ginekologi RSUD Dr. Moewardi \\ 3. Departemen Gizi Fakultas Kedokteran Universitas Sebelas Maret
}

Korespondensi : saskianandatari55@gmail.com

\begin{abstract}
ABSTRAK
Pendahuluan: Persalinan prematur adalah persalinan yang terjadi pada usia kehamilan sebelum 37 minggu. Persalinan prematur disebabkan oleh berbagai faktor, salah satunya yaitu anemia. Anemia dalam kehamilan, keadaan Hemoglobin ibu hamil dibawah $11 \mathrm{~g} / \mathrm{dl}$ yang cukup sering terjadi terutama di negara berkembang. Keadaan ini mengakibatkan penurunan jumlah oksigen yang dibawa ke janin sehingga mengakibatkan hipoksia pada janin serta menstimulasi hormone-hormon stress yang berkaitan dengan induksi persalinan. Tujuan penelitian ini adalah untuk mengetahui hubungan antara anemia pada ibu hamil dengan kejadian persalinan prematur di RSUD Dr. Moewardi Surakarta.

Metode Penelitian: Penelitian observasional analitik dengan pendekatan case control, dilakukan pada Agustus-September 2019 di RSUD Dr. Moewardi. Subjek penelitian adalah pasien yang mengalami persalinan prematur dan persalinan tidak prematur dalam kurun waktu Juni 2017 sampai dengan Juni 2019 di RSUD Dr. Moewardi. Penelitian dilakukan dengan mengolah data rekam medis. Pada penelitian dipilih sebanyak 70 sampel penelitian, yang terdiri masing-masing 35 sampel untuk kelompok kasus dan kontrol. Sampel diambil menggunakan purposive sampling. Data kemudian dianalisis menggunakan uji Korelasi Koefisien Kontingensi Uji Kappa dan uji T-test Tidak Berpasangan.

Hasil: Didapatkan korelasi antara anemia dengan kejadian persalinan prematur yang bermakna secara statistik. Nilai korelasi $(\mathrm{p}=0,031)$ menunjukkan korelasi positif dengan kekuatan korelasi yang signifikan dan bermakna secara klinis. Selain itu, didapatkan perbedaan yang bermakna dan signifikan antara rata-rata nilai Hemoglobin ibu hamil dengan persalinan prematur dan tidak prematur, dengan nilai $(p=0,003)$.

Simpulan: Terdapat hubungan yang signifikan dan bermakna antara anemia pada ibu hamil dengan kejadian persalinan prematur di RSUD Dr. Moewardi Surakarta pada Juni 2017 Juni 2019, dimana anemia pada ibu hamil meningkatkan risiko terjadinya persalinan prematur.
\end{abstract}

Kata Kunci: Anemia, Persalinan prematur

ABSTRACT
Background: Premature labor is labor that occurs at gestational age before 37 weeks.
Premature labor is caused by various factors, one of which is anemia. Anemia in
pregnancy, hemoglobin condition of pregnant women under $11 \mathrm{~g} / \mathrm{dl}$ which is quite
common, especially in developing countries. This situation results in a decrease in the
amount of oxygen carried to the fetus, resulting in hypoxia in the fetus and stimulates stress
hormones associated with labor induction. The purpose of this study was to determine the
relationship between anemia in pregnant women with the incidence of preterm labor in Dr.
Moewardi Surakarta.
Methods: This study was analytic observational research with case-control approach,
conducted in August-September 2019 at Dr. Moewardi. Research subjects were patients 
Nandatari, et al., Hubungan Anemia pada Ibu Hamil dengan Kejadian Persalinan Prematur di RSUD Dr. Moewardi Surakarta

who experienced preterm labor and non-preterm labor in the period June 2017 to June 2019 at the RSUD Dr. Moewardi. The study was conducted by processing medical record data. In this study 70 research samples were chosen, consisting of 35 samples for the case and control groups. Samples were taken using purposive sampling. Data were then analyzed using the Kappa Test Contingency Coefficient Correlation test and the unpaired T-test.

Result: The correlation between anemia and preterm labor was statistically significant. Correlation value $(p=0.031)$ shows a positive correlation with the strength of the correlation that is significant and clinically meaningful. In addition, a significant and significant difference was found between the average hemoglobin value of pregnant women with preterm and non-preterm labor, with a value $(p=0.003)$.

Conclusion: There is a significant and significant relationship between anemia in pregnant women and the incidence of preterm labor in Dr. Moewardi Surakarta in June 2017 - June 2019, where anemia in pregnant women increases the risk of preterm labor.

\section{Keywords: Anemia, Preterm labor}

\section{PENDAHULUAN}

Berdasarkan hasil Survei Demografi dan Kesehatan Indonesia (SDKI) tahun 2017 menunjukkan Angka Kematian Neonatal (AKN) sebesar 15 per 1.000 kelahiran hidup, Angka Kematian Bayi (AKB) 24 per 1.000 kelahiran hidup, dan Angka Kematian Balita (AKABA) 32 per 1.000 kelahiran hidup $^{1}$

Menurut WHO (2018), penyebab utama dari kematian anak dibawah 5 tahun adalah komplikasi dari kelahiran prematur, pneumonia atau infeksi respirasi akut, komplikasi masalah dalam persalinan, kelainan kongenital dan diare. Kematian anak di bawah 5 tahun sebanyak $47 \%$ merupakan kematian neonatal ${ }^{2}$

Neonatal adalah bayi baru lahir sampai dengan usia 28 hari. Penyebab utama kematian neonatal adalah prematuritas. Prematuritas adalah persalinan yang terjadi pada usia kehamilan sebelum 37 minggu. Angka kejadian prematur yang tinggi masih menjadi pusat perhatian dunia. Dalam satu tahun, sekitar 15 juta bayi dilaporkan lahir prematur. Ini artinya lebih dari 1 bayi lahir prematur dalam 10 kelahiran. Lebih dari $60 \%$ prematuritas terjadi di Afrika dan Asia Selatan. Indonesia menduduki posisi ke-5 dalam daftar 10 negara dengan jumlah kelahiran prematur tertinggi di dunia yaitu 675.700 dan posisi ke-9 dalam daftar 10 negara dengan angka kelahiran prematur tertinggi, yaitu 15,5 dalam 100 kelahiran $^{3}$

Persalinan prematur disebabkan oleh berbagai faktor, diantaranya yaitu infeksi, kehamilan ganda atau multifetal, preeklampsia, merokok, dan anemia ${ }^{4}$

Anemia dalam kehamilan merupakan masalah yang cukup sering terjadi terutama di negara berkembang. Lebih dari $52 \%$ wanita hamil di negara berkembang mengalami anemia defisiensi besi ${ }^{5}$.Di Indonesia, proporsi anemia pada ibu hamil meningkat dari $37,1 \%$ pada tahun 2013 menjadi 48,9\% pada tahun $2018^{6}$

Anemia pada ibu hamil bisa disebabkan oleh banyak hal, diantaranya yaitu kekurangan asupan zat besi, asam folat, vitamin B12 dan vitamin A serta infeksi. Anemia yang paling banyak dialami oleh ibu hamil adalah anemia defisiensi besi ${ }^{7}$. Anemia memiliki dampak negatif terhadap ibu hamil seperti kelelahan, meningkatkan risiko cardiac disease, menurunkan sistem imun ibu, dan juga mortalitas. Anemia dalam kehamilan juga memiliki hubungan dengan kejadian prematur dan bayi lahir dengan berat badan rendah ${ }^{8}$. 
Nandatari, et al., Hubungan Anemia pada Ibu Hamil dengan Kejadian Persalinan Prematur di RSUD Dr. Moewardi Surakarta

Penelitian yang dilakukan oleh Larumpaa et al (2017) menyatakan bahwa terdapat hubungan yang signifikan antara anemia dengan kejadian persalinan prematur, dimana ibu yang mengalami anemia memiliki risiko lebih tinggi untuk mengalami persalinan prematur'. Penelitian tersebut menggunakan metode cross sectional, sedangkan pada penelitian yang dilkukan peneliti menggunakan case control.

Angka prematur dan anemia yang tinggi di Indonesia membuat peneliti tertarik meneliti topik ini. Rumah Sakit Umum Daerah Dr. Moewardi Surakarta adalah rumah sakit tipe A, yaitu rumah sakit rujukan tertinggi sehingga sebagian besar kasus yang ditangani adalah kasus rujukan, termasuk persalinan prematur.

\section{SUBYEK DAN METODE}

Penelitian ini dilaksanakan pada bulan Agustus dan September di bagian Rekam Medis Rumah Sakit Umum Daerah Dr. Moewardi Surakarta. Penelitian ini merupakan penelitian observasional analitik dengan pendekatan case-control. Sampel pada penelitian ini adalah data rekam medis pasien persalinan prematur dan tidak prematur di Rumah Sakit Umum Daerah Dr. Moewardi dalam kurun waktu bulan Juni 2017 hingga Juni 2019.

Peneliti mengambil data dari populasi yang ada sesuai dengan kriteria inklusi dan eksklusi yang telah ditetapkan. Sampel dikelompokkan menjadi dua kelompok, yaitu kelompok kasus dan kelompok kontrol yang jumlahnya sama.

Penelitian ini dilakukan menggunakan data sekunder dengan mengutip data rekam medis pasien persalinan prematur dan tidak prematur di RSUD Dr. Moewardi pada bulan Juni 2017 hingga Juni 2019. Dari 338 jumlah pasien persalinan prematur, diperoleh 35 sampel untuk kelompok kasus. Sedangkan dari 50 pasien persalinan tidak prematur, diperoleh 35 sampel yang memenuhi kriteria inklusi dan eksklusi untuk kelompok kontrol. Peneliti menetapkan 35 sampel kasus dan 35 sampel kontrol.

\section{HASIL}

1. Uji Korelasi Koefisien Kontigensi antara Anemia dengan Persalinan Prematur

Tabel 1. Uji Korelasi Koefisien Kontingensi

\begin{tabular}{|c|c|c|c|c|}
\hline \multirow{2}{*}{$\begin{array}{c}\text { Ibu } \\
\text { Hamil }\end{array}$} & \multicolumn{2}{|c|}{ Hemoglobin } & \multirow[t]{2}{*}{$\mathrm{P}$} & \multirow{2}{*}{$\begin{array}{l}\text { Odds } \\
\text { Ratio }\end{array}$} \\
\hline & $\begin{array}{c}\text { Anemia } \\
\mathrm{n}(\%)\end{array}$ & $\begin{array}{c}\text { Tidak } \\
\text { Anemia n } \\
(\%)\end{array}$ & & \\
\hline Prematur & $24(68,6)$ & $11(31,4)$ & 0,031 & 3,273 \\
\hline $\begin{array}{l}\text { Tidak } \\
\text { Prematur }\end{array}$ & $14(40,0)$ & $21(60,0)$ & & \\
\hline Total & $38(54,3)$ & $32(45,7)$ & & \\
\hline
\end{tabular}

Hasil pada Tabel 1. menunjukkan bahwa dari penelitian ini, didapatkan 24 pasien $(68,6 \%)$ mengalami anemia pada kelompok kasus, dan 14 pasien (40\%) mengalami anemia pada kelompok kontrol.

Dari hasil uji korelasi antara dua variabel didapatkan $(\mathrm{p}=0,031)$. Nilai ini menunjukkan bahwa terdapat hubungan yang signifikan antara anemia dengan kejadian persalinan prematur, dimana nilai $(\mathrm{p}<0,05)$. Selain itu, didapatkan nilai Odds Ratio pada penelitian ini adalah 3,273.

\section{Uji T-test Tidak Berpasangan}

Tabel 2. Hasil Uji T-test Tidak Berpasangan

\begin{tabular}{lll}
\hline Persalinan & Jumlah & $\begin{array}{l}\text { Sig (2- } \\
\text { failed) }\end{array}$ \\
\hline Prematur & 35 & 0,003 \\
Tidak Prematur & 35 & \\
\hline
\end{tabular}

Pada tabel 2. Menunjukkan bahwa terdapat perbedaan rata-rata nilai Hemoglobin pada masin-masing kelompok. Rata-rata nilai $\mathrm{Hb}$ pada ibu yang mengalami persalinan prematur lebih rendah yaitu 9,86 $\pm 1,49$, 
sedangkan pada kelompok ibu yang tidak mengalami prematur memiliki rata-rata nilai $\mathrm{Hb} 11,09 \pm 1,29$. Hasil uji T-test didapatkan nilai Sig (2-tailed) $=0,003$, dimana artinya terdapat perbedaan rata-rata nilai $\mathrm{Hb}$ yang signifikan antara ibu yang mengalami persalinan prematur dan tidak prematur, karena Sig (2-tailed) $<0,05$.

\section{PEMBAHASAN}

Peneliti menggunakan uji korelasi kontingensi untuk mengetahui hubungan dari kedua variabel yaitu anemia dan persalinan prematur. Hasil uji ini dapat dilihat pada tabel 1. Hubungan dikatakan signifikan apabila $\mathrm{p}<0,05$. Pada uji ini didapatkan nilai $\mathrm{p}=0,031$. Nilai ini menunjukkan bahwa terdapat hubungan yang kuat atau signifikan antara nilai hemoglobin dengan persalinan prematur, dimana ibu dengan anemia lebih berisiko mengalami persalinan prematur. Selain itu, pada penelitian ini didapatkan juga nilai $O d d s$ Ratio yaitu 3,273. Nilai ini menyatakan bahwa ibu yang mengalami anemia 3,273 kali lebih berisiko mengalami persalinan prematur.

Tabel 2. merupakan hasil analisis nilai hemoglobin kelompok kasus dan kelompok kontrol dengan uji T-test Tidak Berpasangan, menunjukkan bahwa $\mathrm{p}=0.003$, artinya terdapat perbedaan rata-rata yang signifikan $(\alpha<0,05)$ antara nilai $\mathrm{Hb}$ pada ibu hamil dengan persalinan prematur dan ibu hamil tidak dengan persalinan prematur, dimana nilai Hemoglobin pada ibu dengan persalinan prematur lebih rendah daripada nilai Hemoglobin ibu dengan tidak persalinan prematur.

Hasil dari penelitian ini menunjukkan bahwa nilai $\mathrm{Hb}$ ibu hamil yang persalinan pematur memiliki nilai rata-rata $9,86 \pm 1,49$ $\mathrm{g} / \mathrm{dl}$. Sedangkan Ibu yang tidak mengalami persalinan prematur memiliki nilai $\mathrm{Hb}$ dengan rata-rata $11,09 \pm 1,29$ Artinya ibu yang mengalami persalinan prematur memiliki nilai rata-rata $\mathrm{Hb}$ yang rendah dan termasuk dalam kategori anemia dibandingkan ibu yang tidak mengalami persalinan prematur.

Berdasarkan hasil penelitian, dari 35 sampel kasus ditemukan 24 sampel mengalami anemia, dimana pasien yang mengalami anemia ringan sebanyak 13 sampel $(54,17 \%)$, anemia sedang sebanyak 9 sampel $(37,5 \%)$, dan anemia berat sebanyak 2 sampel $(8,3 \%)$. Sedangkan pada 35 sampel kelompok kontrol ditemukan pasien yang mengalami anemia sebanyak 14 sampel, dimana anemia ringan sebanyak 7 orang (50\%) dan anemia sedang sebanyak 7 orang $(50 \%)$.

Hasil penelitian ini didukung beberapa penelitian sebelumnya, diantaranya yaitu penelitian oleh Larumpaa et al, Beckert et al, Ulfa et al, dan Kumar et al. Larumpaa et al (2017) menyatakan bahwa terdapat hubungan yang bermakna antara anemia dan persalinan prematur, dimana anemia meningkatkan risiko terjadinya persalinan prematur. Penelitian yang dilakukan oleh Beckert et al (2019) menyebutkan bahwa ibu hamil dengan anemia meningkatkan risiko persalinan prematur sebanyak $8,9 \%$ dibandingkan dengan yang tidak anemia. Hasil penelitian ini juga didukung oleh penelitian Ulfa et al (2013) di Padang bahwa rata-rata nilai Hemoglobin ibu dengan persalinan prematur lebih rendah daripada rata-rata nilai Hemoglobin ibu tidak persalinan prematur, dimana ibu dengan anemia 4,297 kali lebih berisiko mengalami persalinan prematur. Penelitian yang dilakukan oleh Kumar et al (2013) di India juga mendukung hasil penelitian ini, dimana hasil penelitiannya menyatakan bahwa dari 1000 ibu hamil, lebih dari 50\% mengalami anemia dan ibu yang anemia meningkatkan risiko terjadinya persalinan prematur sebanyak $11,5 \%$ 9,10,11,12.

Beberapa penilitian lain memiliki hasil yang berbeda, diantaranya yaitu penelitian oleh Zhang et al (2017) di China yang menyatakan bahwa Hemoglobin yang rendah 
pada masa kehamilan tidak memiliki korelasi yang signifikan dengan kejadian persalinan prematur ${ }^{13}$.

Hubungan anemia pada ibu hamil dengan kejadian prematur disebabkan oleh berbagai mekanisme. Selama hamil, wanita mengalami perubahan fisiologis, tidak terkecuali perubahan pada hematologis, dimana terjadinya peningkatan ekspansi volume darah dimana plasma darah meningkat sekitar 30$40 \%$ sedangkan eritrosit meningkat sekitar 20$25 \%$. Peningkatan plasma darah yang lebih besar menyebabkan peningkatan kebutuhan zat besi dan asam folat. Peningkatan ini mengakibatkan meningkatnya eritropoetin yang menyebabkan konsentrasi relatif hemoglobin, hematokrit dan eritrosit menurun. Kebutuhan besi yang meningkat dan tidak dapat dipenuhi oleh ibu mengakibatkan kondisi anemia ${ }^{14}$.

Kadar hemoglobin yang rendah dapat merangsang perubahan angiogenesis plasenta dan mengakibatkan keadaan hipoksia pada janin $^{15}$. Anemia menyebabkan berkurangnya nutrisi dan oksigen yang disalurkan ke janin. Hal ini menyebabkan keadaan hipoksia. Keadaan hipoksia akan menginduksi stres pada ibu dan janin yang mengakibatkan pelepasan corticotropin releasing hormone $(\mathrm{CRH})^{16}$.

Fungsi dari corticotropin releasing hormone (CRH) yaitu sebagai regulator utama dalam pelepasan adrenocorticotropic hormone (ACTH). Peningkatan $\mathrm{CRH}$ menstimulasi produksi dari ACTH oleh hipofisis. Peningkatan dari ACTH akan menyebabkan peningkatan hormon kortisol. Peningkatan kortisol ini akan menghambat efek dari progesterone, karena kortisol memiliki afinitas yang lebih tinggi terhadap placental glucocorticoid receptors. Sehingga peran hormon progesterone yang memiliki fungsi mempertahankan kehamilan dengan mempertahankan rahim tetap dalam kondisi tenang akan menurun ${ }^{\mathbf{1 7}, 18}$.
Sekresi ACTH juga akan meningkatkan sekresi dari estrone (E1), estradiol (E2) dan estriol (E3). Peningkatan hormon estrogen ini pada akhirnya akan mengaktifkan aktivitas prostaglandin, reseptor oksitoksin, dan enzim yang bertanggung jawab untuk kontraksi otot miometrium. Hal ini akan memicu terjadinya persalinan prematur ${ }^{19}$.

\section{SIMPULAN}

Berdasarkan hasil penelitian yang telah dilakukan, dapat disimpulkan bahwa terdapat hubungan yang bermakna dan korelasi yang kuat antara Anemia pada Ibu Hamil dengan Kejadian Persalinan Prematur di RSUD Dr. Moewardi, korelasi dengan nilai $\mathrm{p}$ sebesar 0,031. Hasil dari uji T-test Tidak Berpasangan menunjukkan bahwa terdapat perbedaan yang signifikan antara nilai rata-rata Hemoglobin ibu yang mengalami persalinan prematur dengan ibu yang tidak mengalami persalinan prematur, dimana nilai Hemoglobin ibu dengan persalinan prematur lebih rendah. Ibu dengan anemia 3,273 kali lebih berisiko mengalami persalinan prematur.

\section{SARAN}

1. Perlu dilakukan penelitian lanjutan mengenai jenis anemia yang dialami, onset anemia, serta faktor-faktor perancu lainnya seperti gaya hidup, infeksi, dan lain-lain agar hasil lebih akurat.

2. Perlu dilakukan penelitian lanjutan terkait faktor demografis yang mempengaruhi status anemia dan persalinan prematur.

\section{UCAPAN TERIMA KASIH}

Peneliti mengucapkan terima kasih kepada semua pihak yang telah terlibat dan membantu dalam penyelesaian penelitian ini, terutama kepada dosen pembimbing dan penguji. 


\section{DAFTAR PUSTAKA}

1. Direktoral Jenderal, K. K. (2017) Laporan kinerja ditjen kesehatan masyarakat tahun 2016. Kementerian Kesehatan Republik Indonesia.

2. WHO (2018). New global estimates on preterm birth published. https://www.who.int/reproductivehealth/glo bal-estimates-preterm-birth/en/ -- Diakses pada Maret 2019

3. WHO (2018). Pretem birth https://www.who.int/news-room/factsheets/detail/preterm-birth -- Diakses pada Maret 2019

4. Asl AAH, Safari S, Hamrah MP. (2017). Epidemiology and related risk factors of preterm labor as an obstetrics emergency. Emergency, 5(1): e3.

5. Sato APS, Fujimori E, Szarfarc SC, Borges AL, Tsunechiro MA. (2010). Food consumption and iron intake of pregnant and reproductive aged women. Scielo, 18(2):247-54

6. Departemen Kesehatan RI (2018). Riset Kesehatan Dasar; RISKESDAS. Laporan Departemen Kesehartan RI. Jakarta

7. Taner CE, Ekin A, Solmaz U, Gezer C, Cetin B, Keleşoğlu M, Erpala MB, Mehmet Özeren M. (2015). Prevalence and risk factors of anemia among pregnant women attending a high-volume tertiary care center for delivery. Journal of the Turkish German Gynecology Association, 16: 231-236.

8. Stephen G, Mgongo M, Hashim TM, Katanga J, Pedersen BS, Msuya SE. (2018). Anaemia in pregnancy: prevalence, risk factors, and adverse perinatal outcomes in northern tanzania. Hindawi, 2018: 1-9

9. Larumpaa FS, Suparman E, Lengkong R. (2017). Hubungan anemia pada ibu hamil dengan kejadian persalinan prematur di RSUP prof Dr. R. D. Kandou Manado. Jurnal e-Clinic (eCl), 5 (1) : 12-14

10. Beckert RH, Baer RJ, Anderson JG, JelliffePawlowski LL, Rogers EE. (2019). Maternal anemia and pregnancy outcomes: a population-based study. Journal of Perinatology.

11. Ulfa A, Ariadi, Elmatris. (2017). Hubungan antara anemia pada ibu hamil dan kejadian persalinan preterm di RSUP M. DJamil padang tahun 2013. Jurnal FK Unand, 6 (3) : 559-563

12. Kumar KJ, Asha N, Murthy DS, Sujatha MS, Manjunath VG. (2013). Maternal anemia in various trimesters and its effect on newborn weight and maturity: An observational study. International Journal of Preventive Medicine, 4(2) : 193-199.

13. Zhang Y, Li Z, Li H, Jin L, Zhang Y, Zhang L, Liu J, et al. (2017). Maternal haemoglobin concentration and risk of preterm birth in a chinese population. Journal of Obstetrics and Gynaecology.

14. Adam I, Ali AA. (2016). Anemia during pregnancy. In Tech, pp : 113-123.

15. Figueiredo ACM, Gomes-Filho IS, Silva RB, Pereira PPS, Mata FAFD, Lyrio AO, Souza ES, et al. (2018). Maternal anemia and low birth weight: A systematic review and meta-analysis. Nutrients, 10(5) : 601

16. Huang LL, Gowreesunkur P, Su MW, Lin LZ, Hui $T$ (2015). The influence of irondeficiency anemia during the pregnancy on preterm birth and birth weight in south china. Journal of Food and Nutrition Research, 3(9): 570-574.

17. Allen LH. (2001). Iron-deficiency anemia: Biological mechanisms that might underlie iron's effects on fetal growth and preterm birth. American Society for Nutritional Science, 31(2S-2):581S-589S.

18. Bronstein, M.D., 2011. Physiology and Patophysiology of the HPA Axis. In: Cushing's Syndrome. 1 st Ed. Patophysiology, Diagnosis, and Treatment. New York: Springer, 1-13.

19. Ganong, WF. (2015). Medula dan Korteks dalam Fisiologi Kedokteran Edisi 24. Jakarta : EGC. pp 329-340 